\title{
Development, urban planning and political decisions. A triad that built territories at risk
}

\author{
Alejandro Lara ${ }^{1}$ D $\cdot$ Felipe Bucci ${ }^{2}$ Cristobal Palma ${ }^{3} \cdot$ Juan Munizaga ${ }^{4}$. \\ Victor Montre-Águila ${ }^{5}$
}

Received: 31 December 2020 / Accepted: 24 June 2021 / Published online: 6 July 2021

(C) The Author(s), under exclusive licence to Springer Nature B.V. 2021

\begin{abstract}
Chilean geography exposes the country to high-level risks such as earthquakes and tsunamis. The disasters of 1930, 1960, 2010, and 2014 testify to the continuous link between human survival and disasters. However, new hazards have appeared ever since -i.e. flood waterlogging, wildfires, and landslides-, highlighting the relationship between current land uses and space occupation with increasing levels of disaster risk. This research aims to determine relations and responsibilities of the Chilean developmental approach in urban planning and territorial governance processes that have created new territories prone to disaster risk. We resort to a longitudinal analysis from 1930 to 2018 at the Gran Concepción metropolitan area as a proxy of Chilean industrialization and economic development approaches. To do so, we developed mixed-approach descriptive research, for which we collected data from national development policies and documented land occupation processes during pre-dictatorship, dictatorship and post-dictatorship periods. Semi-structured interviews with decision-makers involved in current territorial policy were also carried out. The findings show how territorial governance resulted from political visions around different development paths, wherein the concept of risk is weakly perceived among decisionmakers. This perception is linked to narrow economic goals and the understanding of land as a barely regulated marketable asset, profoundly affected by segregated urban planning.
\end{abstract}

Keywords Development studies · Urban governance $\cdot$ Risk governance $\cdot$ Risk perception · Spatial planning

Alejandro Lara

alejandrolara@udec.cl

1 Department of Architecture, Faculty of Architecture Urbanism \& Geography, University of Concepcion, Barrio Universitario S/N Concepción-Chile, Concepción, Chile

2 Management of the Built Environment, Delft University of Technology, Delft, The Netherlands

3 Department of Architecture, Management and Resilience Architecture for Disaster Risk Reduction Master Program, University of Concepción, Concepción, Chile

4 Faculty of Environmental Sciences, University of Concepcion, Concepción, Chile

5 Catholic University of the Holy Conception, Concepción, Chile 


\section{Introduction}

\subsection{Background}

Since the beginning of this century, cities have become the natural habitat for humans, expanding at unprecedented rates (Wang et al. 2018) and transforming areas unsuitable for urbanization into populated service-based centres (Serra 2011). In 2014, more than 54\% of the worldwide population lived in cities, and by 2050 it is expected to skyrocket to nearly $70 \%$, especially in developing countries (UNDESA Population Division 2015). This scenario increases energy demand progressively, worsening greenhouse gas emissions, aggravating the consequences of climate change and the effects of extreme weather events such as droughts, floods and storms. Hence, affecting both human settlements and the biodiversity of the planet critically (Parece and Campbell 2013; IPCC 2014; Connelly and Bar 2016; Polo Díaz 2016; Seeliger and Turok 2013).

In this context, cities become vulnerable to stressful situations, emphasizing their development's dynamism (Cohen 2006; Roggema 2014). Climate vulnerability can be understood based on the concepts of exposure, sensitivity and ability to adapt to the climate (Mal et al. 2012; IPCC 2014). Cities possess limited ability to reorganize and adapt their built environment, being prevailing design and urban planning approaches uncapable of solving scenarios of increased vulnerability (Villagra et al. 2016; Loyd and Peel 2006), despite international consensus on the role of urban planning in improving adaptation to climate change and building resilient communities (Tolulope et al. 2019; Meerow et al. 2016; James et al. 2016). This issue has been extensively discussed for example, the needs for principles to conduct an integrated balanced and rational use of space (Garcia and Mogrovejo 2010), focused on conserved ecological processes and functions how the key for sustainability approaches it was already mentioned by the European Framework of Territorial Planning (1983). In Latin America and the Caribbean, the idea of incorporating urban planning and management mechanisms to protect and restore biophysics systems is to date shared by many countries in the region (Red et al. 2013; CEPAL 2001). Some have even proposed to implement coordinated actions to improve and foster the integrated environmental and natural resources management (Bello et al. 2020). A regional action plan established the relevance of developing a sustainable approach to environmental protection and preventing natural disasters using a sustainable urban planning approach (U.N., 2020 \& Gómez 2003). Bugliarello (2006) notes that core challenges of urban sustainability result from the intersection of two global concerns: on the one hand, the ability of cities to thrive and progress over time; on the other hand, the need to reduce their impact over global ecological systems. What is more, Jabareen (2006) analyses dominating urban proposals in the discussion for sustainable development and, among the inherent characteristics of any type of discussion over sustainable urban form, he identifies the following: compactness, sustainable transport, density, mixed land uses, passive solar design and the greening of urban areas.

Interconnected sustainable and resilient urban development in a context of climate change and emergent risk shows the urgency to make political progress in agreements that ensure the implementation and effectiveness of the Sustainable Development Goals and the New Urban Agenda (U.N 2017; Lara et al. 2018). However, the lack of a systemic understanding of risk, evident in both scientific knowledge and representative democracy has restricted the ability to integrate and organize local interests, organizations, and social groups in general with environmental needs and economic interests (Le Galés 1995; De 
Marchi and Ravetz 1999), because of lacking concepts such as complexity, relational information and collective intelligence to inform risk management in the future (UNDRR 2020). Such limitations hinder the urgent development of integrative overviews from coming up with managerial approaches and developing much-needed policy responses to reduce systemic risks in scenarios dominated by uncertainty.

Considering the uncertain scenario that we face to date, Sanders (2010) claimed that the adaptation to a changing world is the task of resilient thinking, which seeks to recognize, in the words of Masys (2015), the complex nonlinear and dynamic qualities of interdependent systems (i.e. social, political, economic and ecological). It requires adopting and implementing integrated policies and plans to promote inclusion, efficient use of resources, mitigation, and adaptation to climate change. To do so, societies should understand risks as a product of human actions, and therefore that the built environment making and functioning should be understood as a cyclical process dealing with changing climates and evolutionary priorities, lifestyles, and social values. McLellan et al. (2016) and Connelly and Bar (2016) call to focus on temporal and spatial changes, which implies: firstly, to work at the level of different interested parties, for the design, adoption and implementation of urban planning policies, focused on the common good and not only on economic premises; secondly, to count on States to safeguard harmonious territorial development approaches, through planning tools banning land uses that affect environmental well-being and generate socio-spatial segregation; thirdly, to incorporate climate change adaptation as a cross-cutting axis in public economic policy. Thus, emphasizing the development and construction of safer, more sustainable and resilient territories.

In Chile, developmental approaches implemented since the late 1930s, such as the import substitution industrialization economic model and free-market economics, have had distinctive impacts on territorial development. Following such approaches, territorial planning and governance have preferred unregulated and permissive practices wherein urban planning too often appears too late in ways that go against rationality and sustainability. Such processes have increased the probability of extreme events occurrence (Gómez 2003; Aliste et al. 2012; Rojas et al. 2015, 2019). The urban population growth in the developing countries figure out a complex scenario and challenges to urban systems, especially understanding that the consolidation of the centroperipheral model has moved vulnerable urban people into much more exposed areas. This research aims to analyse the urban transformations of the Great Concepción area as a proxy case study of Neoliberal economic growth. Our article is designed as a descriptive and longitudinal approach, so to determine relations and responsibilities between historical development approaches and deep territorial inequalities in the creation of new territories prone to disaster risk. The period from 1930 to 2018 was selected and divided into three different development phases.

\subsection{The case of study}

To date in Chile, planning-based approaches prevail in a context underpinned by the spontaneous evolution of free-market logics and power groups without considering the common good (Aliste and Rabi 2012).The evolution of such approaches leads to the emergence of economic activities disconnected from the environment, which turns unsustainable in the long term by becoming generalized behaviour. Often in Chilean urban areas, such a territorial imbalance has produced a disorder in land use and occupation, with subsequent environmental degradation. Some places have even been called in 'sacrifice zones' as they 
concentrate major polluting industries and conflicts between local interests and interests derived from power groups (Valdivieso 2004).

For instance, industrial development, which, with the promises of job opportunities and economic prosperity at the local level, cannot often be equated with the environmental costs affecting local populations. In this context, various industrial centres have arisen throughout history around cities such as Valparaíso and Concepción, whose rise has been closely linked to coal, steel, and port development. Both the cities' growth and occupation went through different characteristic periods, which in various ways, transformed the city following the prevailing model.

The area called Gran Concepción-Greater Concepción, or GC-(Aliste et al. 2012) is in the country's southern central area coast of the Biobío Region (Fig. 1). This area is adjacent to the Biobio River and the Andalién River, its main river courses. Its location is between $36^{\prime} 35^{\prime}$ and $37^{\prime} 00^{\prime}$ south latitude and $72^{\prime} 45^{\prime}$ to $73^{\prime} 15^{\prime}$ west longitude. It comprises six communes: Talcahuano, Concepción, Hualpén, Chiguayante, Penco, and San Pedro de la Paz, making up a population of approximately a million inhabitants, more than half of the population of the entire Biobio Region (Instituto Nacional de Estadística 2017). In economic terms, the GC area possess a wide range of economic activities, including the petrochemical industry, fishing and commercial terminals, and various services and commercial activities that attract visitors from all over the country.

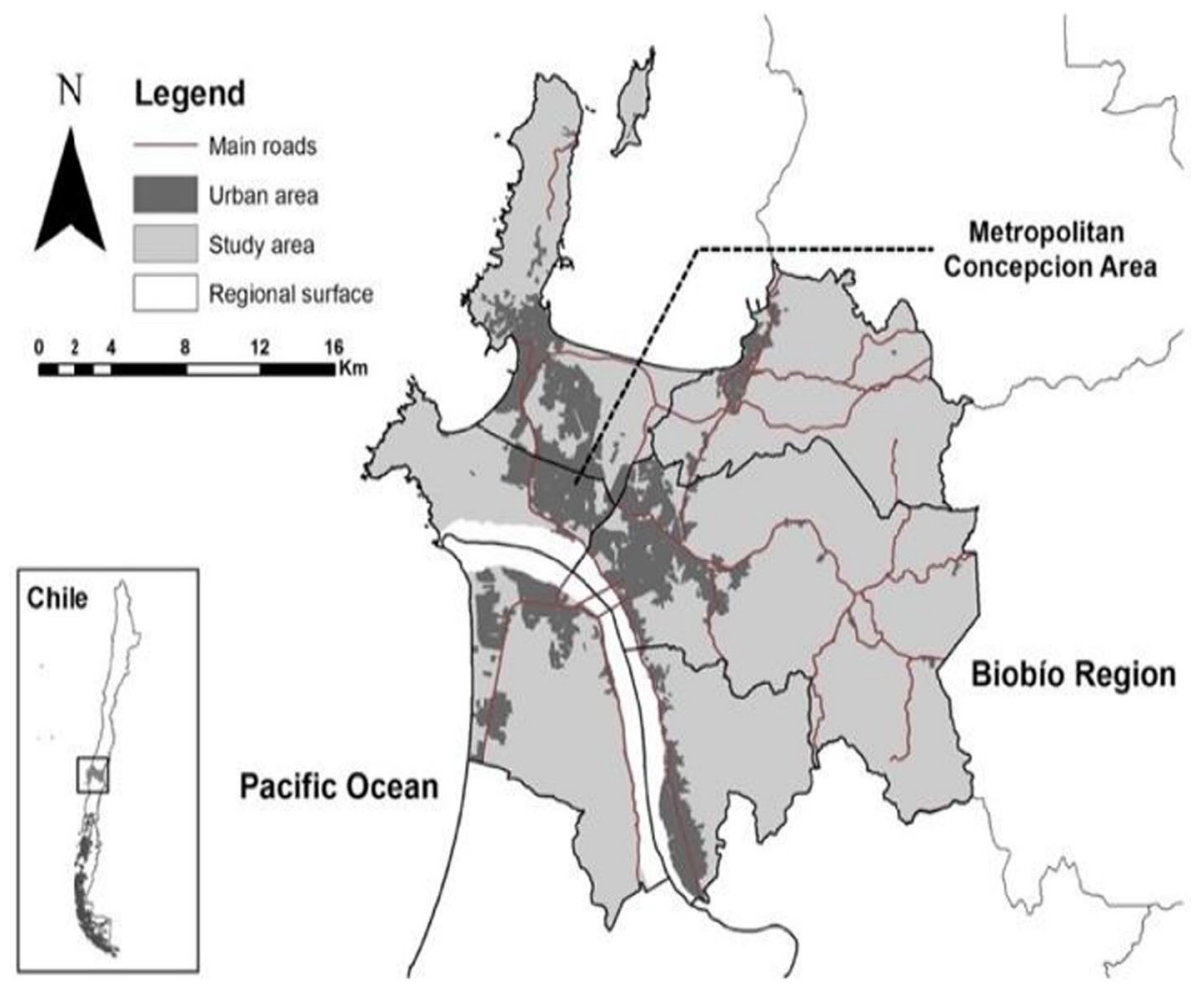

Fig. 1 Area studied. Source: Developed by the authors 
Disastrous situations have become part of the daily life of the people living at the GC. The swelling of rivers Andalién and Biobío have commonly led to river floods throughout history (Rojas et al. 2014), with a recurrence rate of approximately seven years. Waterlogging as a product of excessive rainfall, enhanced by the El Niño pattern, contributes to rapid floods in the low-rise areas (Rojas et al. 2018). Biomass removal is another lifealtering threat in the GC area (Mardones and Vidal 2001); which affects slopes and bluffs of hills wherein low-quality housing conditions add to a high population density. Earthquakes and tsunamis in the GC have been documented since its foundation. In the XX century, 11 earthquakes over seven on the Richter Scale occurred in Concepción, with a 20 years recurrence rate (Quezada 2015). On February 27, 2010, an earthquake of magnitude 8.8 Mw triggered a Tsunami that affected more than 200,000 people, including the death of 23 people, the destruction of roughly 7000 homes, and immeasurable environmental and economic losses (Martínez and Aranguíz 2016; Contreras and Winckler 2013).

$\mathrm{GC}$ is also relevant because of its economic progress in recent decades, which has in turn increased the urban population considerably while positioning the GC as the second most relevant metropolitan area in the country. Such growth has required the continuous creation and adaptation of territorial planning instruments to meet ever-increasing residential needs and the proliferation of industrial activities. However, such processes have also created unbridled urban expansion phenomena, which in turn generate negative consequences on territories, the environment and land uses (Aliste et al. 2012).

The national civil protection system (SNPC) defines disaster risk management in the country. The actions of the SNPC are executed and developed in different national subsystems at the communal, provincial and regional levels (Supreme Decree No. 156/2002 of the Ministry of Internal Affairs), in charge of structuring and steering emergency governance and crisis response (Sandoval et al. 2020). This is done mainly through coordination during the response phase of the risk cycle, following a centralized and linear approach, wherein issues such as inequality, inequity and heterogeneity of the territories deepen vulnerabilities, as disaster risk management is not part of the development or urban planning processes (Maturana et al. 2019).

\section{Materials and methods}

This research is descriptive and uses a mixed methodological approach due to the different data and performed analyses (González 1997). The research design (Fig. 2) considers a case study as it refers to a defined study object, as an entity within the context and considered relevant to be studied (Patton, 1990 \& Perez 2001).

Regarding data collection, we used the following techniques:

(a) Archive analysis to address the historical study of the legislation and public policy that prevailed for development and the creation of territorial planning instruments. Hence, this research was divided into three phases according to political governance criteria: (1) Socialist development approach (1930-1975); (2) Development during the dictatorship (1976-1989) and (3) Economic growth in democracy (1990-2018).

(b) A spatial and temporal analysis of land use and natural hazards was performed using ArcGIS 10.4. Such analysis generated maps and tables comparing land use over the three phases. To understand the changes in land uses in the GC, we decided to create three scenarios from aerial photographs. Land-use categories were proposed based on 

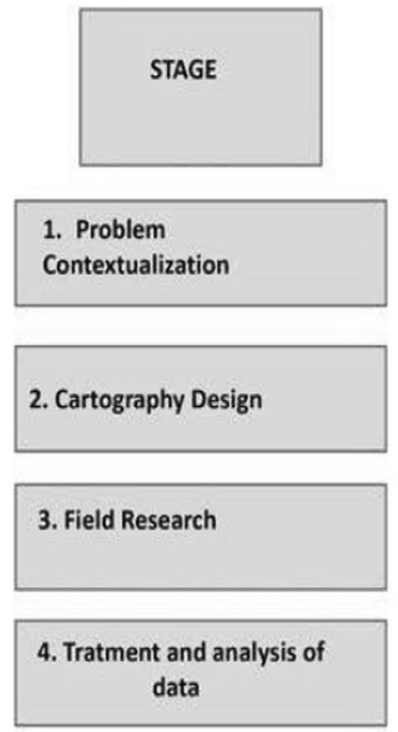

5. Assessment and discussion Of results
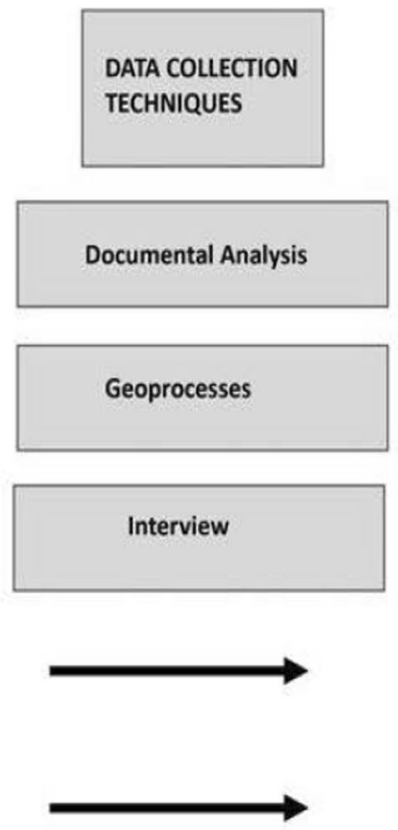

\section{EVIDENCE}

Identification of the processes and Influences of development and urban Planning approaches

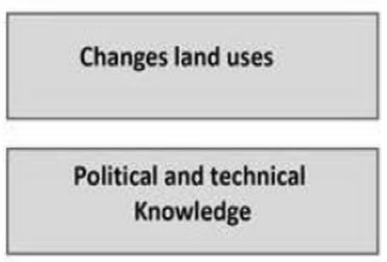

Presentation of results

Discussion \& conclussion proposals

Fig. 2 Methodological process. Source: Developed by the authors, adapted from Lara et al. (2018)

Table 1 Typology of land uses. Source: Developed by the authors, based on Rojas et al. (2018)

\begin{tabular}{ll}
\hline Land use & Description \\
\hline Urbanization & Built for housing, industry and road infrastructure \\
Forest \& plantation & Exotic forest plantation and native forest \\
Water bodies & Lagoons, lakes, rivers, estuaries and ocean \\
Wetlands & Marshes, swamps and temporarily flooded sectors \\
Dunes \& beaches & Stabilized and vegetated dunes, beaches and banks \\
Grasslands & Natural grasslands \\
Bare soils & Soils devoid of vegetation and clear-cut sectors \\
Agriculture & Land for cultivation \\
\hline
\end{tabular}

Rojas et al. (2018) and were summarized in eight categories (Table 1); the photo interpretation technique was done on ArcGIS 10.4. After interpreting land uses, we came up with a summary of land surfaces and its variations to thus understand and describe the trends that occurred in terms of urban land uses. Later, consideration was given to risks associated with the study area (Mardones and Vidal 2001) to understand the relationship between changes in land uses and socio-natural risks, such as waterlogging, floods, tsunamis, and tsunamis landslides. Subsequently, we presented the results in tables and maps to describe the affected area and to quantify total affected surfaces. We finally came up with a final diagnosis and trend analysis. 
(c) We also conducted semi-structured interviews with decision-makers at the government level with expertise in development policies and risk reduction to understand the under-research concepts and their future vision. To select the interviewees, we followed the classification of Social Aspects and Stakeholders Involvement proposed in the Integrated Flood Management methodology by WMO (2006). Sampling by logical criteria (Patton 1990) was also applied to build inclusion criteria that required the interviewees to have a position with territorial decision-making capacity and to belong to an administrative unit of local and-or regional government scale. A total of 14 interviews were carried out: 6 to public servants with technical responsibility for local urban development; 6 to local councilors (1 per each Municipality in the study area); 1 to a regional councilor; and 1 to a public servant responsible for regional development). Before conducting the interview, the informants signed a consent letter. The interviews were then recorded and transcribed in MS Word.

For this study, the interviews consisted of 11 questions grouped into four dimensions: 1. Economic development 2. Urban development 3. Territorial Planning Instruments (TPI) 4. Socio-natural risks and climate change regarding the formulation and typology of the questions, the design of the instrument follows the principles established by Patton (1990), related to the experiences, opinions and knowledge that the interviewees had regarding the dimensions mentioned above.

The gathered information was used for the phases of exploratory, descriptive and interpretive analysis (Krippendorff 1990). For this, we applied two coding methods: a thematic content analysis, which allowed the construction of categories of meaning from interviewees' ideas and a qualitative software Nvivo 12 to describe codes frequency. Finally, and following the recommendations of the United Nations (UN 2017; UNDRR 2020) where disaster risk is understood as a systemic, interdependent and interconnected governance process. We adapt Kooiman's theory (2003) on interactions (Fig. 3). That seeks to understand the complexity, dynamism and diversity of political relations in a context configured

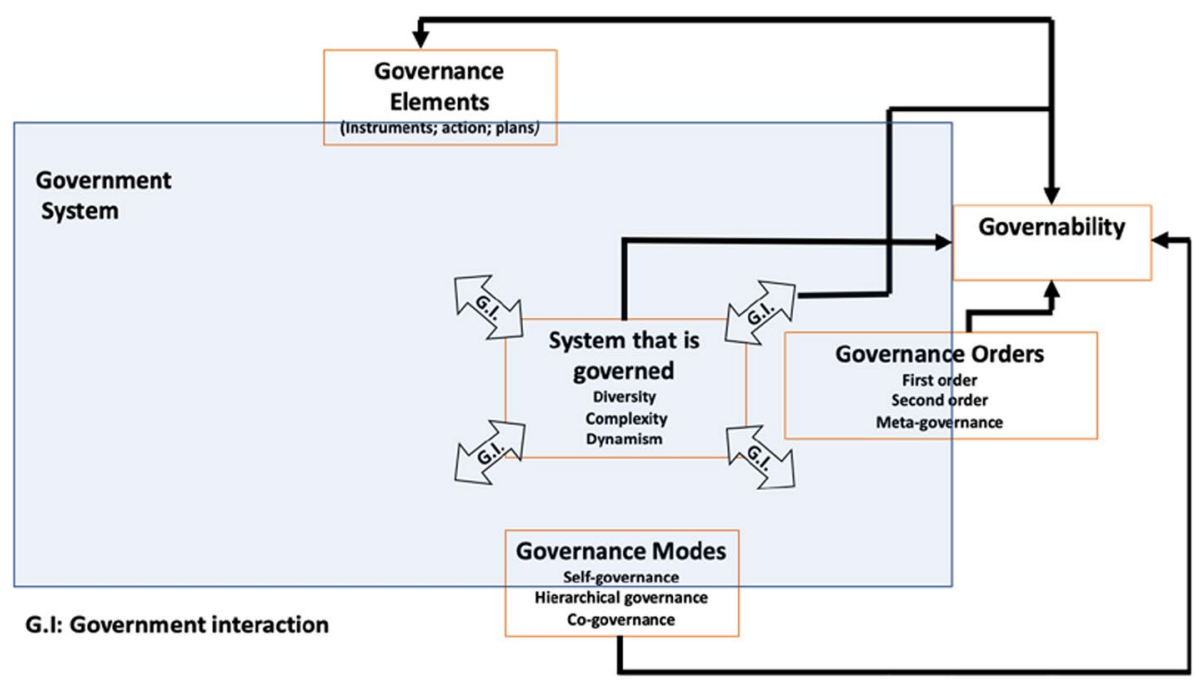

Fig. 3 Kooiman's framework on governance interactions. Source: Kooiman (2003) 
by the state, society and the market. This methodological focus on the governed system interactions between and within the modes of governance (how power is exercised). The elements of governance (instruments and plans that materialize the form of governing). Orders of governance (an organized form of interaction to achieve its purposes at different scales) and governability (the system's total governance capacity). Understanding that the variables studied in the interview produces multilateral relationships representing differentiated views, dependences, interests and ambitions.

\section{Results}

\subsection{Development policy, urban governance and risk scenarios}

\subsubsection{The first period (1930-1975)}

After shocking externalities, the growth poles model was tested (Geisse 1983). It all started by creating the Production Development Corporation (CORFO, in Spanish), for the mass production of goods and services. The industrial impulse of the 1940s paved the ground to install industrial complexes in the area, such as the port of San Vicente, the National Petroleum Company (ENAP), Huachipato Steelworks, a division of the Pacific Steel Company (CAP), among others. This fact might be considered the leading cause for rural-urban migration processes in the GC area, motivated by the new workforce demanded developing such industries, which in turn resulted in a phenomenon of unbridled urban expansion (Aliste et al. 2012).

The 1960s brought the regularization of urban planning throughout the national territory, particularly in large metropolitan areas such as the GC (Muñiz et al. 2015). Territorial Planning Instruments existing at the time intended to be consistent in their idea of a city and its urban development in the medium-term. On the one hand, the development of the Talcahuano Master Plan in 1960 made the importance of the industry in the territory evident by assigning almost $32 \%$ of the total land to industrial uses. In the case of the Master Plan of Concepción, intentions sought to limit, on the one hand, the possible impacts of urban expansion to the natural environment. On the other hand, the possible economic impacts of infrastructure and equipment to an urban environment that was already at risk of uncontrolled growth. The Master Plan of Concepción allocated $62 \%$ of the territory landuse to mixed residential areas, $32 \%$ to services, and did not consider industrial zones, even though specific footwear and minor manufacturing industries did exist. The Intercommunal Master Plan of 1963 aimed to promote the economy on a medium scale, limiting the spatial dispersion of settlements, to strengthen the relationship between housing and industrial areas. However, since the beginning of the 1970s, specific processes of environmental deterioration linked to the developmental approach became evident, enabled by the dictatorship in place that imposed neoliberal policies over political and economic affairs.

It is significant to mention to the end of the period (1975), the role of Forests and Plantations in land uses with $65 \%$ of the total area. It also identifies $9 \%$ (Table 2) of urban land, as mentioned above, closely linked to the development of the GC as an industrial pole, largely absorbing population from rural areas. Urban planning was gaining importance as a regulator of urban expansion, concentrating urban development close to industrial development and service centres, and in some way, restricting growth towards forest areas. 
Table 2 Quantification of land uses, by period studied. Source: Developed by authors, from documentary analysis, following public information of regional and local urban planning instruments

\begin{tabular}{lcrrrrr}
\hline \multirow{2}{*}{ Land use } & \multicolumn{7}{l}{ Surface and variation per year } \\
\cline { 2 - 7 } & 1975 ha & $\%$ & 1989 ha & $\%$ & 2018 ha & \\
\hline Urbanization & 6009 & 9 & 8371 & 13 & 12,733 & 19 \\
Forest and plantation & 42,709 & 65 & 39,862 & 61 & 39,899 & 61 \\
Water bodies & 4832 & 7 & 4784 & 7 & 4770 & 7 \\
Wetlands & 2550 & 4 & 2060 & 3 & 1336 & 2 \\
Dunes and beaches & 157 & 0 & 159 & 0 & 114 & 0 \\
Grasslands & 4752 & 7 & 2874 & 4 & 4022 & 6 \\
Bare soil & 1842 & 3 & 4607 & 7 & 2251 & 3 \\
Agriculture & 2844 & 4 & 2978 & 5 & 570 & 1 \\
Total & 65,695 & 100 & 65,695 & 100 & 65,695 & 100 \\
\hline
\end{tabular}

\subsubsection{The second period (1976-1989)}

During the dictatorship, the development approach sought to provide regional territories with necessary natural resources to support their prospects for economic development based on comparative advantages. The 1979 National Policy for Urban Development (PNDU in Spanish) proved to be the clearest materialization of the neoliberal model over urban issues. Throughout its pages, Urban land was defined as a non-scarce resource, for which uses would be decided based on greater profitability and flexible legal provisions, following market requirements. Smith and Romero (2009) point out that since 1975, the urban expansion of the GC area occurred at the expense of the occupation of valuable areas for biodiversity conservation-mainly wetlands-which in turn deteriorated the environmental quality of such ecological areas.

Furthermore, this period was marked by the eradication of the poorest groups from the inter-commune into the periphery, resulting in precarious urbanization and a lack of urban equipment. The demographic growth reflected the percentage at the end of the period, going from the previous one, from 6 to 13\% of urban land use, in an increase of more than 2000 hectares. Real estate development established the need to resort to new land, which can be corroborated by the percentage of such increase in the bare ground (from 3 to $7 \%$ of surface area) and the decrease in grasslands (from 7 to $4 \%$ ). The degradation and occupation of fragile environments such as wetlands began to be relevant, as shown in Table 2, with a decrease of almost 500 hectares, showing the special interest and value that the economic model had for land.

The 1980s witnessed the beginning of forestry monoculture, which shaped the GC area's natural landscape, mainly in the Coastal Mountain Range. This use maintained at higher than $60 \%$ of the total area. In 1985, the prevailing political regime created a new National Policy for Urban Development because of the effects of the preceding PNDU implemented in 1979. This new document established the need for rethinking the country's urban development because "of the upcoming crisis of the concept of urban planning, as the policy adopted in 1979 had partially undermined the legitimacy of the efforts that, effectively or not, had been implemented until then" (MINVU 2012, p. 38). Thus, urban development at the mercy of the market had to be replaced by a slightly more restrictive role of the State. Likewise, the concept of land as a non-scarce resource replaced completely, categorizing it as an economically scarce resource "due to its nature as a non-produced and useful good, 
Table 3 Land use affected by floods and waterlogging along periods of time studied. Source: Developed by the authors from documentary analysis, following public information of regional and local urban planning instruments

\begin{tabular}{|c|c|c|c|c|c|c|}
\hline \multicolumn{4}{|l|}{ Affected by flood } & \multicolumn{3}{|c|}{ Affected by waterlogging } \\
\hline Land use & 1975 (ha) & 1989 (ha) & 2018 (ha) & 1975 (ha) & 1989 (ha) & 2018 (ha) \\
\hline Urbanisation & 396 & 625 & 1 & 418 & 492 & 587 \\
\hline Forest and plantation & 387 & 375 & 232 & 104 & 94 & 86 \\
\hline Water bodies & 4683 & 4658 & 4664 & 16 & 13 & 11 \\
\hline Wetlands & 1774 & 1637 & 1212 & 42 & 3 & 0 \\
\hline Dunes and beaches & 17 & 25 & 10 & 0 & 0 & 0 \\
\hline Grasslands & 1139 & 1082 & 1700 & 75 & 59 & 30 \\
\hline Bare soil & 190 & 192 & 78 & 6 & 43 & 7 \\
\hline Agriculture & 618 & 610 & 191 & 62 & 19 & 2 \\
\hline Total & 9204 & 9204 & 9204 & 723 & 723 & 723 \\
\hline
\end{tabular}

Table 4 Land use affected by tsunami \& landslide along periods of time studied. Source: Developed by the authors, from documentary analysis, following public information of regional and local urban planning instruments

\begin{tabular}{|c|c|c|c|c|c|c|}
\hline \multicolumn{4}{|l|}{ Affected by tsunami } & \multicolumn{3}{|c|}{ Affected by landslide } \\
\hline Land use & 1975 (ha) & 1989 (ha) & 2018 (ha) & 1975 (ha) & 1989 (ha) & 2018 (ha) \\
\hline Urbanization & 1220 & 1554 & 1978 & 41 & 70 & 123 \\
\hline Forest and plantation & 507 & 416 & 219 & 2149 & 2016 & 2044 \\
\hline Water bodies & 1615 & 1602 & 1613 & 42 & 42 & 42 \\
\hline Wetlands & 2298 & 1942 & 1266 & 5 & 3 & 1 \\
\hline Dunes and beaches & 106 & 106 & 85 & 2 & 2 & 1 \\
\hline Grasslands & 699 & 751 & 1.552 & 54 & 24 & 43 \\
\hline Bare soil & 234 & 167 & 32 & 66 & 180 & 127 \\
\hline Agriculture & 83 & 224 & 17 & 24 & 46 & 2 \\
\hline Total & 6762 & 6762 & 6762 & 2383 & 2383 & 2383 \\
\hline
\end{tabular}

whose supply is inelastic" (MINVU 2012, p. 44). Through the percentage, it identified as following the increase in urban use, accompanied by the rise in the affectation or damage in the four threats analysed (Tables 3 and 4), with notable variations in the floods caused by flooding of rivers, evidencing the effects of permissive urban expansion towards river beds.

\subsubsection{The third period (1990-2018)}

From a political-administrative perspective, this period characterized by the continuity and deepening of the free market economy (Maturana 2017), the 1985 PNDU, and the limited government initiative to update this national policy. It was only between 1993 and 1996, following the creation of the Territorial Development Policy, that, for the very first time, a citizen consultation phase was considered in a territorial policy-making process, which sought for endogenous growth of cities through the intensification of existing urban land occupation. However, urban development in the GC consisted of urban expansion over 
areas of natural value at a growth rate of 204.7 hectares per year (Smith and Romero 2009) until the early 2000s. When economic activities of the GC are considered, the conditions of the previous decade remained virtually the same, except for the total and final decline of the coal industry in the towns of Coronel and Lota (nearby the GC) and the fishery crisis Talcahuano. Such a crisis resulted from the overexploitation of fishery resources and exacerbated by the industrial city's environmental crisis. It was a disaster that brought the city to the brink of collapse because of sparse and flexible environmental regulations.

The dawning of the new millennium began with the recognition of natural resources misusage at the regional level, with direct responsibility laying on poor environmental management, the outsourcing of the economy, and housing deployment (Aliste 2013). However, residential land-uses increasingly expanded into natural interest and ecosystem conservation areas, destroying more than 1100 hectares of wetlands (Rojas et al. 2019). The G.C., the city of Concepción, was consolidated as a service-based centre. San Pedro de la Paz and Chiguayante were assigned for almost exclusive residential uses, with Hualpén and Penco progressively joining the latter purposes. Talcahuano saw the rise of mackerel fishing and, in turn, the end of the incremental development process based on the steel and oil industries, which no longer generated new jobs. At the same time, services increased for populations farther from the centrality of Concepcion. Construction became an attractive economic activity, where all actors wanted involvement (Hidalgo 2007). The progressive increase in urban populations positively correlated with the continuous development of new real estate projects, which transformed the city's urban image, expanding the limits of the localities towards more traditional sectors. Thus, densification in high-rise construction, single-family homes in condominiums, and an increase in land value were the reactions to territorial planning instruments that allowed a high rate of construction which generated an optimal market (Toledo 2019).

In this period, the increase in urban development was remarkable, with a variation of more than 4000 hectares (from 13 to $19 \%$ of surface area), where non-restrictive urban planning patronizes real estate markets. The places of natural value such as wetlands continued in their progressive decrease and occupation for the city's expansion, together with productive land (see Table 2), in the almost disappearance of agricultural activity (from 5 to $1 \%$ of the surface). Although they remained virtually unchanged, the forest areas continued replacing the native forest with monoculture plantations, stimulate by deregulation of rural areas and slow protection through Territorial Planning Instruments. On the other hand, the growing increase in the urbanization of hillsides has created areas of the urbanforest interface of high exposure increasing forest fires risk and landslide (Harnecker et al. 2020). The percentages show how the urban area affected by landslide move from 41 hectares in the first period of analysis to 123 hectares in the last one. It shows that it is a relevant danger in the study area, especially for construction on slopes.

The findings show that the developmental approaches have had a particular impact on territorial development (Aliste et al. 2012). Consequently, the urban area of the GC area doubled from 9 to $19 \%$ between the first and last periods (Table 2). This incidence affected the urban and real estate development, which indicates an expansion of urbanization and loss of natural systems characterized by peripheral growth; the natural water barriers imposed by the Biobío River; and the progressive destruction of the wetlands (Rojas et al. 2015). Market decisions benefitted from flexible legislation and outdated territorial planning tools, especially within coastal and river plains, mouths of rivers and estuaries.

Highly eroded environments and an abrupt topography increased the likelihood of extreme events fostering the emergence of new areas at risk (Rojas et al. 2019; Smith and Romero 2009; Mardones 2001). This scenario supports Aliste et al. (2012), stating a 


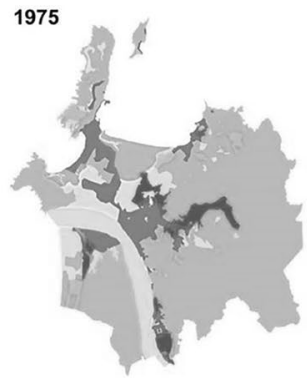

Symbology

- Urbanization

Forest plantation
1989

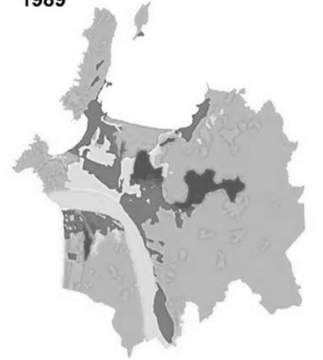

Beaches and dunes Grasslands

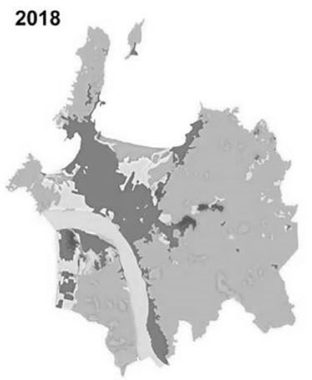

Bare soil - Agriculture
$0 \quad 3,5 \quad 7$ $\stackrel{3,5}{-1}$

Fig. 4 Context of change in land use in the Great Concepción area. Source: Developed by the authors from Landsat images and documentary analysis, following public information of regional and local urban planning instruments

relationship between the built environment and the biophysical setting, which perceived as an obstacle to development (Fig. 4). The scenario mentioned above complements the issues raised in the characterization of the problem in the study area and the analysis of changes in land use. Such changes have deepened the understanding of risk identified in the G.C. area, where continuous land-use transformations lead to high urban concentrations in areas exposed to risk. It noted that all areas described in land use of the G.C. had been affected mainly by the tsunami, landslide or river flooding, except waterlogging, which has no incidence in dunes and beaches.

\subsection{Decision-makers perception of development and risk approach relationship}

The results of the interviews developed through a process of categorization of information. Initially, data were identified within the information collected to be later reordered according to the aforementioned theoretical categories, seeking information about the dimensions and topics of interest that configured the data collection (Table 5). The perception of decision-makers about urban risk and policies varied and depended on knowledge, urban development strategies, territorial planning instruments, and the approach to risk in the different

Table 5 Dimension and topics for data collection. Source: Developed by the authors

\begin{tabular}{ll}
\hline Dimension & Topics of interest for data collection \\
\hline Urban development strategy & To identify and prioritize economic activities \\
& Impact of economic activities on the territory \\
& Relation between economic activities and risk \\
& To identify urban governance approach \\
& To recognize main milestones of urban development \\
Territorial planning instruments & To identify territorial planning instruments (TPI) \\
& Relation between TPI, urban development and risk \\
Natural risk threats & To identify and prioritize risk \\
Risk management approach & To indicate action and measures to risk management \\
& Relation between risk and other dimensions
\end{tabular}


communes of the Great Concepción Area. And regarding the analysis of relationships, the implemented governance modes are characterized by being a top-down approach, regulating all the relationships, interactions, and coordination in the Great Conception. Sectoral visions, uncommon interests and differentiated knowledge about the concept of risk and its management promote the design and implementation of hierarchical urban public policies emphasizing economic development over environmental variables (Fig. 5).

It is possible to infer that the decision-makers do not have a shared vision about incorporating risk variables into the territorial development plans, revealing that the relationship between the development approach in urban areas and new risk scenarios not addressed correctly. While the effects are identifiable for most decision-makers, designing new strategies and plans is not perceived as relevant in the present. For example, only one territorial program has incorporated aspects linked to risk and climate change but not from a systemic approach, meaning that ad-hoc strategies used and, so far, preferred to cope with crises. Here, local decision-makers have also been slow to realize that the degradation of natural systems is becoming a source for deepening affecting social systems, especially the health and quality of most vulnerable people.

The GC does not have a common strategy for risk and disaster management, presenting partial responses that vary according to territorial instruments and knowledge of present and future threats. This reality could hurt the urban and economic development policies, affecting industrial production processes, citizens' consumption practices, sales of services, and the active population's ability to carry out job duties in a sustainable approach.

The main results can be summarized as follows.

\subsubsection{Urban development strategy}

According to the interviewees, the urban development strategies implemented in this study case (new neighbourhoods, green areas; island hills, urban wetlands, coastal edge protection and urban channels) display the transition process towards a sustainable development

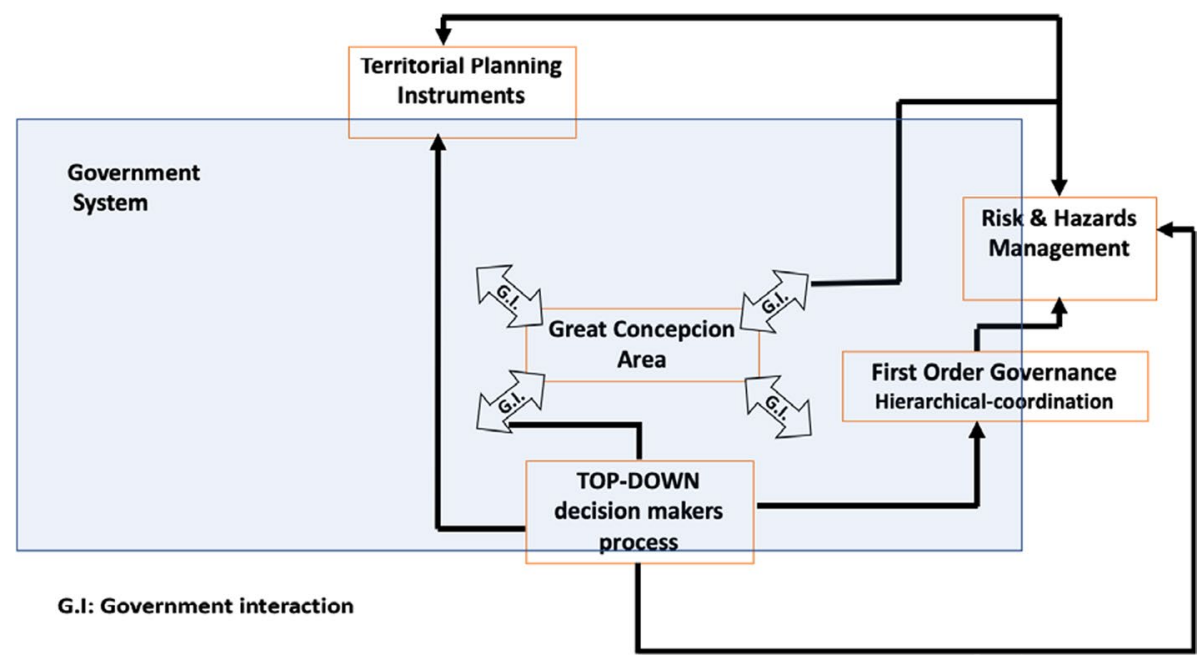

Fig. 5 Decision makers interaction in the creation territories at risk. Source: Developed by the authors from interviews and Kooiman (2003) adaptation 
approach, incorporating the traditional model of economic production in the Biobío region with the demands of citizens. For the key informants, the territory's urban development has directly linked to imposed economic development priorities. Land, as market stock, has been transformed into goods of high private and political interest, which drives the urban development of the city. Likewise, the interviewees indicated that the implemented urban development strategies arise about prevailing economic activities. 33.3\% of the answers associate them with the booming real estate activity (considered the main economic activity in the territory). Also, $20 \%$ of interviewees said that forestry is a necessary urban development strategy for certain municipalities in the metropolitan area. On the other hand, the urban initiatives implemented in neighbourhoods post-earthquake and tsunami of 2010 has fostered growing social, environmental awareness promoting urban development strategies on a citizen scale (forest interface with urban areas (20\% of answers), green areas (20\% of responses), neighbourhood (20\% of responses), sea and river borders (20\% of responses), urban wetlands (13\% of responses), SNASPE (13\% of responses), hills-islands (13\% of responses). Linked to those mentioned above, $20 \%$ of interviewees point out that forestry is a necessary urban development strategy for certain communes in the GC area.

We have talked about the fact that real estate development requires short, medium and especially long-term planning, which is also in line with the development of road infrastructure and connectivity, and also to establish all the corresponding environmental protection. We are talking about many areas of Concepción that are poles of development, and we know that the infrastructure projects are far behind schedule. It is reactive; it is not planning.

\section{Interviewee 1}

The sector that is also growing is real estate, the change of land use and the Master Plan that also allows you to build. Build where you want. You can build a lot.

\section{Interviewee 7}

\subsubsection{Territorial planning instruments}

Territorial planning in the G.C. ruled by instruments such as the Community Development Plan (PLADECO), Local Master Plan, Metropolitan Master Plan and Sectional Plans, which aim to organize the environment based on social, economic and legal criteria, among others. The interviewees acknowledged the existence of Territorial Planning Instruments, especially the Master Plan (100\% of the answers), then the Community Development Plan (66.7\% of the answers) and the Metropolitan Master Plan (66.7\% of the answers). They also acknowledged them having an impact on socio-natural risks. At the same time, the existence of various management instruments with territorial effects appears, which diversifies and does not necessarily generate coherence between sectoral public policies because a tool not applied to all the territorial sceneries of the Great Concepcion.

For the interviewees, although the TPI configure a set of tools to benefit territorial development, the meaning and scope of these instruments do not match the current requirements and the vision of the future presented by the study area and society. For example, they stated that the relationship between development and risk scenarios is known. However, the greater or lesser inclusion of these concepts in the TPI will respond to biased perceptions and interests. 
The comprehensive plans have been divided. We now have the master plan of San Pedro de la Costa (government) is currently working on the master plan Ribera Sur, the entire riverbank, and in parallel, is also working with the development plan of mobility and public space. According to the new norm of inclusive mobility and the new law that they will implement on mobility.

\section{Interviewed 12}

I think, despite all the recent experiences we have in disasters, we still have little legislation and little awareness, perhaps, of natural hazards.

\section{Interviewed 5}

Land use plans and, in my opinion, those that should have the greatest integration related to disaster risk management and which not fulfilled to date.

\subsubsection{Risk management approach}

Among socio-natural risks in the G.C., forest fires, landslide, rainwater flooding, drought, and tsunamis are the most significant risks (over $65 \%$ of answers). Then, river floods, earthquakes, atmospheric pollution, erosion and water pollution represent less than $50 \%$ of the answers. According to the key actors, conurbation has a high prevalence rate, with drought and forest fires being significant due to forest production in the peri-urban area and threats to affect the entire urban system.

The approach to risk threats varies depending on the commune understudy in the TPI with three different perspectives: active, indirect, and non-existent. The active approach linked to updates to territorial instruments, including risk variables in their management, includes local responses to cope with risk scenarios. The indirect practice focuses on disasters, thus managing emergency scenarios through emergency plans, with a reactive action turning around to replenish primary services and immediately help people and damages areas. On the other hand, some local governments do not have a strategy for managing risk scenarios. They argue that risks are not a big issue in the present nor the future. It is evident that socio-natural risks approached in different ways and that there is no standard model. Thus fore, each commune has other regulatory plans with a detailed understanding and approximation of the territory's various threats. They understood that they could not manage disaster events beyond their borders.

When asked about the consequences of socio-natural risks in the economic development of G.C., 73.3\% think that socio-natural risks cause current problems. In the future, they will maintain their importance or that there will appear new problems associated with risks (33.3\% of answers).

Without a doubt, part of the territory is at risk, especially from flooding. If we are surrounded on one side by the bay and the other by the river, we have both.

\section{Interviewed 12}

This was the driest winter in the last 20 years. Therefore, we are going to have a very long season of forest fires, perhaps a little more complex.

\section{Interviewed 14}

Today, a slightly more integrated mentality is being preserved or consecrated, as we have said, through the viewpoint of different actors. Because nowadays, architects, 
the Directorate of Works or the Urban Office intervene in modifying the Master Plan, today, the community is intervening a lot. The Directorate of Environment and the Directorate of Community Development are intervening to capture certain social requirements to raise community demands. Moreover, the Municipality is going to accede to that demand as long as they are well-founded.

Interviewed 1

\section{Discussion}

There exists an international consensus on that, as a society, we all are the ones who contribute to risk building. The original idea that disasters are not natural but a product of the social construction of risk had its first outlines in the writings of Jean-Jacques Rousseau (García 2005). However, on a theoretical level, different meanings have been attributed to it. From the point of view of disasters, it is set beyond the territory's physical-natural conditions; the way we occupy the space also generates risks. Lagos et al. (2008) mention that the non-consideration of the socio-spatial dynamics in space occupation forms in space occupation forms induces disaster risk. Hence, it is essential to establish an understanding of risk that addresses the interrelationships between these socio-spatial dynamics, economic development dynamics, considering those emerging threats and how they are part of the construction of risk. Under this approach, the development models adopted by the countries, the urban governance implemented and the characteristic of political decision in the territorial planning form a triad that has considerable implications in the transformation and management risk.

Is it common to accept that reducing risk requires measures of sustainable and rational planning of the territory, but how do we transform it into concrete actions? For example, the European Union has generated regulations that work closely to reduce risk with land use planning. It is considered one of the most rational, economic and sustainable measures and less aggressive towards the environment. For example, the Spanish case is remarkable considering the accelerated economic and territorial changes it has experienced and its notable progress in understanding socio-natural threats, exposure and vulnerability of cities, with its subsequent inclusion in urban governance. In 2008 the change of State Land Law forced the inclusion of maps of existing risks in the new urban development processes and, thus, effectively incorporated risk reduction in land use planning (Olcina 2011). It had a relevant implication in defining natural hazards in the Spanish territory, improving risk management and assessing territorial and urban regulations. Guided by international reference frameworks from European Union, the water framework directive (2000), the floods framework directive (2007) and the new European Territorial Agenda (2030). Spanish autonomous communities, such as the Basque Country, Catalonia, the Valencian Community, the Balearic Islands, to robustness regulations and specific competencies in risk reduction and governance urban.

In Latin America and the Caribbean, there are several case studies in which the common denominator granted by the neoliberal economic model serves as the basis for establishing comparison guidelines for how risk scenarios are configured. Furthermore, there is the question about how urban governance has been approached within risk management. According with Bello at al., (2020) United Nations Economic Commission for Latin America and the Caribbean) analyses how disaster risk management has been addressed 
in planning instruments of the different countries in the region. Among the analysed tools, development plans and strategies and risk management plans of national and subnational scope stand out, following what is stipulated by the Sendai Framework for Action (goal E) and goals 1.5, 11.b and 13.1 of the 2030 Agenda for Sustainable Development. These plans and strategies are essential as they are used to assess responsibilities related to the various actors in decision-making (governmental and non-governmental) and allowing the study and monitoring of a country's priority risks. Due to this, countries require a solid and wellcoordinated institutional framework and human and financial capacities at all administrative levels. The United Nations Organization for Disaster Risk Reduction (UNDRR 2019) proposed some criteria for development strategies, highlighting the incorporation of the recommendations of priorities 1, 2 and 3 of the Sendai Framework, referring to the understanding of risk, strengthening governance, and investing in risk reduction, respectively.

Among Latin American experiences, Guatemala stands out. A country that has proposed risk reduction measures aimed at improving the its adaptive capacity and resilience of the population and ecosystems. Similarly, Costa Rica focuses on local governance as all its municipalities have local disaster risk reduction strategies. These strategies should include, among other aspects, urban risk management, land use planning and river basin management. In South America, the importance of progress in reducing disaster risk aligned with sustainable development objectives is generally evident. Colombia has focused on their Pact for Sustainability goals, for strengthening the community's knowledge about disaster risks and emerging as a result of climate change, promoting new economies, ensuring natural resources for future generations, and achieving a balance between product development and environmental conservation (Bello et al. 2020).

The research in Chile showed that cities are vulnerable to multi-hazards, evidencing the neoliberal urban development policies implemented, which has led to drastic changes in land use that follow free-market rules, and anthropizing the environment in response to the economic growth framework considering risk factors in the process (Matus et al. 2019). In the GC, urban growth and city expansion over wetlands and riverbeds have increased risk exposure, transferring the poorest to peripheral areas, while increasing their vulnerability to extreme events (Rojas et al. 2017; Napadensky and Orellana 2018). This is evident in post-disaster scenarios. Hidalgo et al. (2019) declare that market-led real estate affected urban policies in the last five decades. As a consequence, people were pushed to use new spaces unfitted for occupation hat in turn deepened socio-spatial segregation. Contreras et al. (2019) reflect that the "pro-business urbanism in Chilean cities" is responsible for the absence of affordable housing in city centres, which has also generated exclusion. The lack of adequate and integrative housing policies has increased the installation of self-built houses in risk areas.

Urban governance has not managed to act on time, considering that disasters do not take long to happen. Here, local and regional decision-makers have also been slow to realize that the degradation of natural systems is becoming a source of threats that affect social systems, especially the health and quality of life of the most vulnerable people and deepening inequalities. Outdated TPI, without social participation, lack of environmental knowledge and short-term vision of development are presented as the main aggravating factors that exacerbate complicity in constructing new territories at risk. In addition, the management approaches seem to tend towards disarticulation rather than integration with development processes, given the still current primary focus on the response and the poor understanding of risk. It confirms that the increase in the socio-spatial vulnerability of the GC has resulted from the intimate relationship among a development approach that prioritizes economic growth over environmental factors. The political decisions have promoted urban 
governance focused on the land market. Real estate with a permissive legal framework has sustained within a system that has decided to establish "sacrifice zones" and continue assisting in emergencies, from a reactive and linear approach to risk management.

This segregated approach is one of the prime goals of Sendai Framework tries to intervene (UNISDRR 2015), defining a new era in the direction of classification, description and management of risks, in which the interconnection of risk governance with the Sustainable Development Goals and the Paris agreements is an essential partnership. That is why the paradigm shift towards systemic risk management is necessary, defining approaches under an integrative vision that allows the development of clear and timely policy responses aimed at coexisting and managing uncertainty for reducing the effects of the disaster. The urban and territorial governance has understood as an action model based on the interaction among multi-actors, oriented towards a systematic process of transformation (Semeraro et al. 2020).

Since the end of the twentieth century, Lefevre (1998) recognized that governance models in urban territorial policies must involve complex systems of actors and different forms of action based on flexibility and the voluntary nature of participation. Accordingly, the global community must establish a flexible and adaptive urban risk governance structure around the complex phenomena to be managed (Lara et al. 2018; Aven 2018). Similarly, it is necessary to encourage collective action to improve decision-making processes, reduce systems breakdown, or minimize their collapse (Ahrend et al. 2019; IRGC 2017). Indeed, challenges call for reforming current urban risk governance configurations through collective action where cities would reorganize and adapt with a focus on committed, attending to a new integrative vision. Furthermore, this goes with the international consensus on the role of urban planning in improving adaptation to climate change and building resilient communities (Tolulope et al. 2019; Meerow et al. 2016; James et al. 2016). Also, risk management must consider concepts such as complexity, relational information, and collective intelligence to achieve a systemic understanding of it and attempt to manage the uncertainty because human life and environmental and economic assets are in danger (Aven 2018; Maturana et al. 2019; Basel et al. 2020).

Consequently, robustness and the re-formulation of risk governance are crucial elements for increasing awareness, meaning, and scope of systemic risks approach (UNDRR 2020; IRGC 2017). Here the methodologies focused on the quantification of risk components are obsolete since they do not allow us to understand and react effectively to emerging phenomena, such as COVID-19 or those derived from climate change (Bulkeley and LuqueAyala 2019). Such methodologies do not contribute to a better understanding of the phenomenon and decrease resilience at different scales (Hossain et al. 2020). They intensify the weaknesses of the political decision-making process that States have, which in turn only deepen ongoing reactive approaches to crises (De Bruin et al. 2020). Understanding emergent risk is part of a systemic context offers an opportunity to glimpse the environmental challenges that we must solve.

\section{Conclusion}

This study highlights that the projected increase in the world's urban population for the coming decades will occur in secondary cities or conurbations in developing countries and not in established cities of the first world. Poverty and the favourable socioeconomic conditions to overcome this in underdeveloped economies will lead to $60 \%$ of human beings 
living in cities by 2030. In this global context, economic models such as the one prevailing in Latin America and Chile generate highly complex challenges to urban systems and land use planning, exposing their weaknesses.

The apparent trends in poorly planned urban development (i.e. flexibility in land uses for real estate supply and the political belief that the natural and ecological systems adjacent to the city are barriers to its development) prove the neoliberal approach to urban development. Although the political regime responsible for this strategy in Chile ceased in 1989, subsequent democratic governments have not been characterized by implementing development policies with a different perspective (for example, based on built environments supported by sustainability principles). The neoliberal development model has influenced segregating urban policies, imposing the location of the least advantaged on the outskirts of the city and in areas of greater environmental fragility, where the natural physical conditions of the environment and occupation of the territory determine a high exposure to threats of natural origin. Market rules have generated a drastic variation in land use over several periods, anthropizing from the centre outwards, approaching and occupying fragile areas, with little consideration of risk in this process. These changes have complicated the understanding of the risk identified in the G.C., where continuous changes in land use led to high urban concentrations in areas exposed to risk.

According to the local and regional actors in the GC, managing disaster risk through land use planning varies from commune to commune and from instrument to instrument, due to uneven knowledge about hazards and the elements that generate the risk in the first place. Despite there is a general framework to consider specific hazards within the identification of each administrative area, there is no approval to understand how to study them, nor an obligation to consider them in risk zoning. In this, the responsibility falls on these actors in their interrelation as decision-makers of urban planning, especially under the requirement that they arrive on time to design new strategies and plans. The latter understanding that the drastic dynamics of urban development contribute to the degradation of natural systems and the construction of risk in contexts where usually the most vulnerable deepen their condition, especially after the disaster occurs.

The GC must undergo conscious transformations for urban and economic development and requires to be led by political decisions that support the transition of cities towards improved sustainability and resilience. Understanding the complexities of the physicalnatural dynamics in contact with urban development inexorably connect social systems in such a systemic whole.

Acknowledgements This study was possible thanks to the following research projects: Ministry of Education, Government of Chile. National Commission for Scientific and Technological Research. CONICYT PAI INSERTION project $\mathrm{N}^{\circ} 79150024$, "Approaches to the development and territorial planning: relationships and responsibilities in the creation of new territories at risk, in the Gran Concepción-Chile". University of Concepcion project $N^{\circ}$ VRID-217.181.001-01.OIN, "Designing security. An approach to the ways of living with natural disasters in Gran Concepción-Chile".

Funding This study was part of the following research projects: Ministry of Education, Government of Chile. National Commission for Scientific and Technological Research. CONICYT PAI INSERTION project No79150024, "Approaches to the development and territorial planning: relationships and responsibilities in the creation of new territories at risk, in the Gran Concepción-Chile" \& University of Concepcion project $\mathrm{N}^{\mathrm{o}}$ VRID-217.181.001-01.OIN, "Designing security. An approach to the ways of living with natural disasters in Gran Concepción-Chile".

Data availability The data used for this manuscript have referenced in the text, with its respective DOI or consultation link. 
Code availability The software analyses data from this research were: the Universidad de Concepcion provides ArcGIS 10.4, Nvivo 12 and their use licenses.

Declaration

Conflict of interest The authors declare that they have no conflict of interest.

\section{References}

Ahrend R, Jin S, Lembcke A, Schumann A (2019) Por qué es importante la gobernanza metropolitana y cómo lograrla. En: Gómez-Álvarez D, Rajack R, López-Moreno E, Lanfranchi G Gobernanza 75Metropolitana: el gobierno de las metrópolis para el desarrollo urbano sostenible. BID, Washington, págs 54-75

Aliste E, Rabi V (2012) Conceive the socio-environmental: representation and representativeness of development discourses. Polis Mag 32:2-14. https://doi.org/10.4067/S0718-65682012000200015

Aliste E, Contreras M, Sandoval V (2012) Industrialization, development and city: socio-demographic and spatial transformations in the social geography of the Great Conception (1950-2010). INVI Mag 27(75):21-71. https://doi.org/10.4067/S0718-83582012000200002

Aliste E (2013) Imaginaries, speeches, representations: the city from its living space. In: Lapez E (Ed) Towards a policy of urban development in Chile: research and visions from the University of Chile. Santiago, Chile: University Editorial. ISBN: 9561124238

Aven T (2018) An emerging new risk analysis science: foundations and implications. Risk Anal 38(5):876888. https://doi.org/10.1016/j.ress.2019.04.035

Basel B, Goby G, Jhonson J (2020) Community-based adaptation to climate change in villages of Western Province, Solomon Islands. Mar Pollut Bull 156:1-18. https://doi.org/10.1016/j.marpolbul.2020. 111266

Bello O, Bustamante A, Pizarro P (2020) Planificación para la reducción del riesgo de desastres en el marco de la Agenda 2030 para el Desarrollo Sostenible. CEPAL. LC/TS.2020/108. p 62. https://repositorio. cepal.org/bitstream/handle/11362/46001/S2000453_es.pdf?sequence=1\&isAllowed=y

Bugliarello G (2006) Urban sustainability: dilemmas, challenges and paradigms. Technol Soc 28:19-26. https://doi.org/10.1016/j.techsoc.2005.10.018

Bulkeley H, Luque-Ayala A (2019) Gobernanza del clima en las regions metropolitanas. En: Gómez-Álvarez D, Rajack R, López-Moreno E, Lanfranchi G (ed) Gobernanza Metropolitana: el gobierno de las metrópolis para el desarrollo urbano sostenible. BID, Washington, págs 220-240

Carta Europea de Ordenación del Territorio (1983) Conferencia Europea de Ministros Responsables de la Ordenación del Territorio. Consultado el 25 de abril de 2021

CEPAL (Comisión Económica para América Latina y el Caribe) (2001) Plan de acción regional de América Latina y el Caribe sobre asentamientos humanos, Versión actualizada, LC/G.2143, Agosto de 2001, Santiago de Chile

Cohen B (2006) Urbanization in developing countries: Current trends, future projections, and key challenges for sustainability. Technol Soc 28:62-80. https://doi.org/10.1016/j.techsoc.2005.10.005

Connelly RI, Bar P (2016) Local networks of resilience and climate adaptation: the case of Istanbul. In: Leal Filho W (ed) Climate change, adaptation, resilience and hazards. Springer, Cham, pp 109-123

Contreras M, Winckler P (2013) Loss of life, housing, infrastructure and boats to the February 27, 2010 tsunami on Chile's central coast. Works Proj 14:6-19. https://doi.org/10.4067/S0718-281320130002000 01

Contreras Y, Neville L, González R (2019) In-formality in access to housing for Latin American migrants: a case study of an intermediate Chilean city. Int J Hous Policy 19(3):411-435. https://doi.org/10.1080/ 19491247.2019.1627841

de Bruin YB, Lequarre AS, McCourt J, Clevestig P, Pigazzani F, Jeddi MZ, Colosio C, Goulart M (2020) Initial impacts of global risk mitigation measures taken during the combatting of the COVID-19 pandemic. Saf Sci. https://doi.org/10.1016/j.ssci.2020.104773

De Marchi B, Ravetz JR (1999) Risk management and governance: a postnormal science approach. Futures 31(7):743-757

European Commission (EC) (2000) Directive 2000/60/EC of the european parliament and of the council of 23 October 2000 establishing a framework for community action in the field of water policy 
European Commission (EC) (2007) Directive 2007/60/EC of the european parliament and of the council of 23 October 2007 on the assessment and management of flood risks

European Territorial Agenda (2030) A future for all places. Informal meeting of Ministers responsible for spatial planning and territorial development and/or territorial cohesion 1 December 2020, Germany. Retrieved 15 May 2020, from https://www.territorialagenda.eu/files/agenda_theme/agenda_data/Terri torial\%20Agenda\%20documents/TerritorialAgenda2030_201201.pdf

García Acosta V (2005) El riesgo como construcción social y la construcción social de riesgos. Desacatos, (19): 11-24. Recuperado en 10 de mayo de 2021, de http://www.scielo.org.mx/scielo.php?script=sci_ arttext\&pid=S1607-050X2005000300002\&lng=es\&tlng=es

Garcia A, Mogrovejo R (2010) Theoretical approaches to development policy: main theories. In: García A (ed) Development Policy, Official Master in International Cooperation and Development Policies, University of Malaga, pp 123-154. Full text in: http://www.mogrovejo.org/archivos/Politica_de_desar rollo.pdf (Class texts)

Geisse G (1983) Economics and policy of urban concentration in Chile, 1st Ed. Mexico: The College of Mexico, PISPAL. ISBN: 968-12-0211-2

Gómez D (2003) La ordenación territorial: carácter, alcance y contenido, Toluca

González M (1997) Methodology of social research. Aguaclara, Alicante

Harnecker B, Vásquez J, Ortega R (2020) Instituto para la Resiliencia ante Desastres. Las publicaciones científicas sobre incendios forestales están creciendo y tienen una gran presencia regional. Obtenido de Conecta Resiliencia. https://conectaresiliencia.cl/investigacion-incendios/

Hidalgo R (2007) Is the land finished in the big city? The new metropolitan peripheries of social housing in Santiago, Chile. EURE (Santiago) 33(98):57-75. https://doi.org/10.4067/S0250-71612007000100004

Hidalgo Dattwyler R, Santana Rivas L, Link F (2019) New neoliberal public housing policies: between centrality discourse and peripheralization practices in Santiago, Chile. Hous Stud 34(3):489-518. https:// doi.org/10.1080/02673037.2018.1458287

Hossain MS, Ramiréz J, Haisch T, Speranza C, Martius O, Mayer H, Keiler M (2020) A coupled human and landscape conceptual model of risk and resilience in Swiss Alpine communities. Sci Total Environ. https://doi.org/10.1016/j.scitotenv.2020.138322

Instituto Nacional de Estadística (2017) Censo de Población y Vivienda. Santiago de Chile: INE

IPCC (2014) Climate change 2014: synthesis report. Contribution of working groups I, II and III to the fifth assessment report of the intergovernmental panel on climate change. In: Core Writing Team, Pachauri RK, Meyer LA (eds) IPCC, Geneva, Switzerland, p 151. ISBN: 978-92-9169-143-2

IRGC (2017) Introduction to the IRGC risk governance framework, revised version. Lausanne: EPFL International Risk Governance centre

Jabareen Y (2006) Sustainable urban forms: their typologies, models, and concepts. J Plan Educ Res 26:3852. https://doi.org/10.1177/0739456X05285119

James K, Thompson-Fawcett M, Jahn C (2016) Transformations in identity, governance and planning: the case of the small city. Urb Stud 53(6):1162-1177. https://doi.org/10.1177/0042098015571060

Kooiman J (2003) Governing as governance. SAGE Publications Ltd, Thousand Oaks

Krippendorff K (1990) Content analysis: an introduction to its methodology. Sage, Pennsylvania

Lagos M, Cisterna M, Mardones M (2008) Construcción de Viviendas Sociales en Áreas de Riesgo de Tsunami. Revista de la Construcción vol 7 (2), pp 4-16. Pontificia Universidad Católica de Chile. Disponible en: https://www.redalyc.org/pdf/1276/127612584001.pdf

Lara A, Reyes LF, Moreno J, Quilodrán P, Sánchez K (2018) Designing happiness? A close-up to the housing reconstruction process after the Chile earthquake and tsunami on 27 February 2010. Nat Hazards 91(2):537-551. https://doi.org/10.1007/s11069-017-3139-1

Le Galès P (1995) Du gouvernement des villes à la gouvernance urbaine. Revue Française de Science Politique, 1

Lefevre C (1998) Metropolitan government and governance in western countries: a critical review. Int J Urb Reg Res 22(1):9-25. https://doi.org/10.22518/usergioa/jour/ccsh/2019.1/a13

Lloyd G, Peel D (2006) City-regionalims: the social reconstruction of an idea in practice. In: Tewdwr-Jones M, Allmendinger P (eds) Territory, identity and spatial planning. https://doi.org/10.4324/9780203008 003

Mal S, Singh RB, Huggel C (2017) Climate change, extreme events and disaster risk reduction: towards sustainable development goals. Springer, New York (ISBN: 9783319564685)

Mardones M, Vidal C (2001) The zoning and assessment of natural geomorphological risks: an instrument for urban planning in the city of Concepción. EURE 27(81):97-122. https://doi.org/10.4067/S025071612001008100006 
Martinez C, Aránguiz R (2016) Tsunami risk and resilient planning of the Chilean coast: the town of Boca Sur, San Pedro de la Paz (37o S). North Big Geogr Mag 64:33-54. https://doi.org/10.4067/S071834022016000200004

Masys A (2015) Disaster management: enabling resilience. Springer, New York

Maturana F, Peña-Cortés F, Ramírez Carrasco F, Telias M (2019) Dinámicas urbanas y transición hacia espacios metropolitanos: el caso de Valdivia y la Región de Los Ríos, Chile. urbe Revista Brasileira de Gestão Urbana 11:e20180143. https://doi.org/10.1590/2175-3369.011.e20180143

Maturana F (2017) Absence of urban planning in Chile? Alguans reflections. Cybergeo: European Journal of Geography. Retrieved 25 August 2018, from URL: http://journals.openedition.org/cybergeo/28064

Matus Madrid CP, Ganter R, Carrasco JA, Barraza Huaiquimilla C (2019) Neoliberal urbanization and synergistic violence in postearthquake Concepción. Lat Am Perspect. https://doi.org/10.1177/00945 $82 X 19879147$

McLellan B, Zhang Q, Farzaneh H, Utama A, Ishihara K (2012) Resilience, sustainability and risk management: a focus on energy. Challenges 3(2):153-182. https://doi.org/10.3390/challe3020153

Meerow S, Newell J, Stults M (2016) Defining urban resilience: a review. Landsc Urb Plan 147:38-49. https://doi.org/10.1016/j.landurbplan.2015.11.011

Ministry of Housing and Urban Planning MINVU (2012) Towards a new national policy of urban development: historical background. Santiago, Government of Chile, United Nations Development Programme. ISBN 978-956-7674-71-8

Muñiz I, Sánchez V, García L (2015) Spatial structure and population density in the ZMVM 1995-2010: evolution of a polycentric urban system. EURE J Reg Urb Stud 41(122):75-102. https://doi.org/10. 4067/S0250-71612015000100004

Napadensky-Pastene A, Orellana-McBride A (2019) Metropolización y organización funcional de sistemas urbanos intermedios. Gran La Serena, Concepción y Puerto Montt. Bitacora 29(1):65-78. https://doi.org/10.15446/bitacora.v29n1.67325

Olcina J (2011) Riesgos naturales y Ordenación Territorial. Nuevos Contextos. Revista Proyección $\left(\mathrm{N}^{\circ}\right.$ 11). Vol V. Instituto CIFOT. Universidad Nacional de Cuyo. Mendoza Argentina, pp 192-209 ISSN: 1852-0006. http://ffyl.uncuyo.edu.ar/upload/n11 completo.pdf

Parece T, Campbell JB (2013) Comparing urban impervious surface identification using landsat and high-resolution aerial photography. Remote Sens 5(10):4942-4960. https://doi.org/10.3390/rs510 4942

Patton M (1990) Qualitative evaluation and research methods. Sages, London

Perez G (2001) Qualitative research. Challenges and questions: I Methods, 3rd edn. The wall, Madrid (ISBN: 84-7133-628-6)

Polo Díaz H (2016) A conceptual framework for understanding vulnerabilities to extreme climate events. In: Leal Filho W (ed) Climate change, adaptation, resilience and hazards. Springer, Cham, pp 143156 (ISBN: 978-3-319-39880-8)

Quezada J (2015) Earthquakes and tsunamis in the Biobío Region. Retrieved 15 May 2015, from http:// www2.udec.cl/gema/main.html

Red C, Muñiz I, Pino J (2013) Understanding the urban sprawl in the mid-size Latin American cities through the urban form: analysis of the Concepción metropolitan area (Chile). J Geogr Inf Syst 5:222-234. https://doi.org/10.4236/jgis.2013.53021t

Roggema R (2014) Towards enhanced resilience in city design: a proposition. Land 3(2):460-481. https://doi.org/10.3390/land3020460

Rojas O, Mardones M, Arumi J, Aguayo M (2014) A review of river floods in Chile period 1974-2013, causes, recurrences and consequences. Geogr J Gt North 57:177-192. https://doi.org/10.4067/ S0718-34022014000100012

Rojas C, Sepulveda-Zúñiga E, Barbosa O, Rojas O, Martínez C (2015) Urbanization patterns in the biodiversity of urban wetlands in Metropolitan Conception. North Gd Geogr J 2015(61):181-204. https://doi.org/10.4067/S0718-34022015000200010

Rojas O, Mardones M, Rojas C, Martinez C, Flores L (2017) Urban growth and flood disasters in the coastal river basin of south-central Chile (1943-2011). Sustainability 9(2):195. https://doi.org/10. 3390/su9020195

Rojas O, Mardones M, Martinez C, Flowers L, Saez K, Araneda A (2018) Flooding in central Chile: implications of tides and sea level increase in the 21 st century. Sustainability 10(12):1-17. https:// doi.org/10.3390/su10124335

Rojas C, Munizaga J, Rojas O, Martínez C, Pino J (2019) Urban development versus loss in a coastal Latin American city: lessons for sustainable land use planning. Land Use Policy 80:47-56. https:// doi.org/10.1016/j.landusepol.2018.09.036 
Sanders M (2010) Assessment of the potential of ecosystem-based approaches to climate change adaptation and mitigation in Europe. Final report to the European Commission, DG Environment, contract no. 070307/2010/580412/SER/B2. Ecologic Institute and Environmental Change Institute, Oxford University Centre for the Environment. Retrieved 15 July 2019 from: http://ec.europa.eu/ environment/nature/climatechange/pdf/EbA_EBM_CC_FinalReport.pdf

Sandoval V, González C, Orellana V, Farías C (2020) Lo que nos espera en Chile: escenario multiamenaza y gobernanza del COVID-19. Retrieved 24 june 2020, from https://www.elmostrador.cl/desta cado/2020/06/18/lo-que-nos-espera-en-chile-escenariomultiamenaza-ygobernanza-del-covid-19/

Seeliger L, Turok I (2013) Towards sustainable cities: Extending resilience with insights from vulnerability and transition theory. Sustainability, 5(5) 2018-2128. https://doi.org/10.3390/su5052108

Semeraro T, Zaccarelli N, Lara A, Cucinelli F, Aretano R (2020) A bottom-up and top-down participatory approach to planning and designing local urban development: evidence from an urban university centre. Land 9(4):1-25. https://doi.org/10.3390/land9040098

Serra A (2011) Turning hazards into resources? Floods, wetlands and climate change in the Mediterranean coast of Spain. Unpublished doctoral thesis, Autonomous University of Barcelona, Spain

Smith P, Romero H (2009) Effects of the urban growth of the Metropolitan Concepción Area on the wetlands of Rocuant-Andalién, Los Batros and Lenga. J North Geogr 43:81-93. https://doi.org/10. 4067/S0718-34022009000200005

Toledo I (2019) Urban effects of building in height. Analysis of urban scale and shadow cones in the built environment. Unpublished research seminar. Architecture Major, Faculty of Urbanism and Geography, University of Concepción, unpublished

Tolulope B, Mukalazi A, Ropo I (2019) Spatial planning and climate change adaptation assessment: perspectives from Mdantsane Township dwellers in South Africa. Habitat Int 90:1-9. https://doi.org/10. 1016/j.habitatint.2019.04.005

U.N (2017) New urban agenda. Habitat III. United Nation ISBN: 978-92-1-132736-6

U.N (2020) 2030 Agenda for sustainable development. United Nations ECLAC-Santiago, Chile. ISBN: 97892-1-058643-6, 2015

UNDESA Population Division (2015) Population 2030: demographic challenges and opportunities for sustainable development planning. United Nations, 58. Retrieved 27 August 2017, http://www.un.org/en/ development/desa/population/publications/pdf/trends/Population2030.pdf

UNDRR (2019) Global assessment report on disaster risk reduction. Geneva, Switzerland: International Strategy for Disaster Risk Reduction. Retrieved 10 April 2020, https://gar.undrr.org/report-2019

UNDRR (2020) United nations office for disaster risk reduction. Retrieved 20 May 2020, https://www.preve ntionweb.net/collections/covid19-systemicrisk

UNIDRR (2015) La Estrategia Internacional para la Reducción de Desastres de las Naciones Unidas. Disponible en www.eird.org

Valdivieso J (2004) ¿Hay un lugar en Rawls para la cuestión ambiental? Isegoría 31:207-220. https://doi. org/10.3989/isegoria.2004.i31.465

Villagra P, Herrmann G, Quintana C, Sepúlveda RD (2016) Resilient thinking and urban planning in a coastal environment under tsunami risk: the case of Mehuín, Chile. J North Geogr 62(64):55-62. https://doi.org/10.4067/S0718-34022016000200005

Wang L, Pijanowski B, Yang W, Zhai R, Omrani H, Li K (2018) Predicting multiple land-use transitions under rapid urbanization and implications for land management and urban planning: the case of Zhanggong District in central China. Habitat Int 82:48-61. https://doi.org/10.1016/j.habitatint.2018.08.007

World Meteorological Organization (WMO) (2006) Social aspects and stakeholders involvement in integrated flood management. Technical Document. Flood Management Policy Series. Geneva: Associated Programme on Flood Management (APFM)

Publisher's Note Springer Nature remains neutral with regard to jurisdictional claims in published maps and institutional affiliations. 